Marquette University

e-Publications@Marquette

Chemistry Faculty Research and Publications

Chemistry, Department of

7-15-2005

Analysis of Liquid-Phase Chemical Detection Using Guided Shear Horizontal-Surface Acoustic Wave Sensors

Zhonghui Li

Yolanda Jones

Jeanne M. Hossenlopp

Marquette University, jeanne.hossenlopp@marquette.edu

Richard Cernosek

Sandia National Laboratories

Fabien Josse

Marquette University, fabien.josse@marquette.edu

Accepted version. Analytical Chemistry, Vol 77, No. 14 (July, 2005): 4595-4603. DOI. (C) 2005

American Chemical Society. Used with permission. 


\title{
Analysis of Liquid-Phase Chemical Detection Using Guided Shear Horizontal-Surface Acoustic Wave Sensors
}

\author{
Zhonghui Li \\ Department of Electrical and Computer Engineering, \\ Marquette University, \\ Milwaukee, WI \\ Yolanda Jones \\ Department of Chemistry, Marquette University \\ Milwaukee, WI \\ Jeanne Hossenlopp \\ Department of Chemistry, Marquette University \\ Milwaukee, WI \\ Richard Cernosek \\ Sandia National Laboratories \\ Albuquerque, NM \\ Fabien Josse \\ Department of Electrical and Computer Engineering, \\ Marquette University, \\ Milwaukee, WI
}

Analytical Chemistry, Vol 77, No. 14 (2005): pg. 4595-4603. DOI. This article is @ American Chemical Society and permission has been granted for this version to appear in e-Publications@Marquette. American Chemical Society does not grant permission for this article to be further copied/distributed or hosted elsewhere without the express permission from American Chemical Society. 
NOT THE PUBLISHED VERSION; this is the author's final, peer-reviewed manuscript. The published version may be accessed by following the link in the citation at the bottom of the page.

\begin{abstract}
Direct chemical sensing in liquid environments using polymerguided shear horizontal surface acoustic wave sensor platforms on $36^{\circ}$ rotated $\mathrm{Y}$-cut $\mathrm{LiTaO}_{3}$ is investigated. Design considerations for optimizing these devices for liquid-phase detection are systematically explored. Two different sensor geometries are experimentally and theoretically analyzed. Dual delay line devices are used with a reference line coated with poly (methyl methacrylate) (PMMA) and a sensing line coated with a chemically sensitive polymer, which acts as both a guiding layer and a sensing layer or with a PMMA waveguide and a chemically sensitive polymer. Results show the three-layer model provides higher sensitivity than the four-layer model. Contributions from mass loading and coating viscoelasticity changes to the sensor response are evaluated, taking into account the added mass, swelling, and plasticization. Chemically sensitive polymers are investigated in the detection of low concentrations (1-60 ppm) of toluene, ethylbenzene, and xylenes in water. A low-ppb level detection limit is estimated from the present experimental measurements. Sensor properties are investigated by varying the sensor geometries, coating thickness combinations, coating properties, and curing temperature for operation in liquid environments. Partition coefficients for polymer-aqueous analyte pairs are used to explain the observed trend in sensitivity for the polymers PMMA, poly(isobutylene), poly(epichlorohydrin), and poly(ethyl acrylate) used in this work.
\end{abstract}

With the increasing threat of the use of biological and chemical weapons, there is a strong interest in investigating sensors for (bio-)chemical sensing in gas or liquid phase. Additionally, regulatory management of wastewaters and commercial agricultural toxins such as pesticide residues in runoff waters presents the need for efficient environmental monitoring. Gas-phase sensing has been extensively investigated for many years, ${ }^{1}$ and very accurate and precise detection of trace organic compounds can be achieved using various technologies such as acoustical, electrical, electrochemical, optical, and MEMS technology. In particular, acoustic wave sensors have been widely employed for the detection of various biochemical compounds in gaseous environments. ${ }^{1-5}$ Following successful application in gas sensing, liquid sensors attracted considerable attention due to the need for real-time, rapid, and direct detection in liquid environments where the device is in direct contact with the solution for applications such as the detection of biochemical warfare agents and environmental contaminants. $\frac{6-10}{}$

Various types of acoustic wave devices have been developed for operation in liquids, including thickness shear mode (TSM), shear horizontal acoustic plate mode, shear horizontal surface acoustic wave (SH-SAW), and flexural plate wave devices. Significant challenges

Analytical Chemistry, Vol 77, No. 14 (2005): pg. 4595-4603. DOI. This article is (C) American Chemical Society and permission has been granted for this version to appear in e-Publications@Marquette. American Chemical Society does not grant permission for this article to be further copied/distributed or hosted elsewhere without the express permission from American Chemical Society. 
exist in effectively implementing acoustic wave devices as chemical sensors in liquid environments. Special considerations are necessary for the device design, the selection of stable and chemically sensitive coatings in liquids, and the design of liquid cells for a flow-through or dip-in systems.

Device stability and sensitivity are of concern, due to the need for low loss and low signal distortion from the added liquid load. Of the acoustic wave devices studied, guided SH-SAW devices appear most promising for biochemical sensing in liquid environments, with the possibility of tailoring the device sensitivity. Guided shear horizontal surface acoustic waves are more sensitive to device perturbation without a high degree of acoustic loss or signal distortion. The guided $\mathrm{SH}-\mathrm{SAW}$ sensor (also known as Love-wave sensor) consists of a $\mathrm{SH}-$ SAW device with an overlayer having a lower shear wave velocity. The purpose of the overlayer is to trap the acoustic energy near the sensing surface, thus making the device more sensitive to surface perturbations. Moreover, a liquid sample can be applied on the device surface without significantly damping the wave due to the fact that the particle displacement is normal to the propagation direction and parallel to the propagation surface. In the present work, SH-SAW devices on $36^{\circ}$ rotated $\mathrm{Y}$-cut $\mathrm{X}$ propagating $\mathrm{LiTaO}_{3}$ are used. A dual delay line configuration, which consists of a reference line and a sensing line, is used to reduce secondary interactions such as temperature. However, when the polymers on both delay lines are not identical, as in this work, the thermal effects will be slightly different on both polymers such that there may be small, typically negligible residual effects that influence the sensor signal. A metallized delay path between input and output interdigital transducers (IDTs) is used to eliminate acoustoelectric interactions with the liquid load. The selected coating, a dielectric material, also helps to reduce acoustoelectric interactions and provides sufficient electrical passivation of the IDTs, due to the relatively larger dielectric constant of the piezoelectric substrate.

Most polymers can be used as the thin guiding layer because of their relatively low shear wave velocity and the ease of surface layer preparation. To decrease the propagation loss, and minimize water absorption, which may cause instability and polymer degradation, 
cross-linking or curing of the polymer coating is necessary. However, a degree of signal attenuation is still needed to suppress the triple transit echo, which may add to the sensor noise and nonreproducibility in delay line configurations.

Detection of targeted analytes requires a chemically sensitive coating on the sensing line to realize maximum sensitivity. Appropriate selection of the partially selective coating is critical for the sensor design, as coatings that are optimal for achieving high sensitivity to analytes in the gas phase may not necessarily be optimal for liquidphase detection, $\underline{11}$ especially for ionic or polar analytes. The process of analyte sorption in liquid-phase sensing can be described by the partition coefficient, $K_{\mathrm{P}-\mathrm{L}}$, which is a thermodynamic parameter that characterizes the distribution of organic analytes between the polymer coating and the aqueous solution. $\frac{12-16}{1}$ This model has been used extensively in the gas phase. Calculation of $K_{\mathrm{P}-\mathrm{L}}$ can be used to predict the relative sensitivity and inherent selectivity of a sensor coating material in liquid environments and is given by

$$
K_{\mathrm{P}-\mathrm{L}}=\frac{C_{\mathrm{P}}}{C_{\mathrm{L}}}=\frac{C_{\mathrm{p}} / C_{\Lambda}}{C_{\mathrm{L}} / C_{\Lambda}}=\frac{K_{\mathrm{P}-\Lambda}}{K_{\mathrm{L}-\Lambda}}
$$

$C_{\mathrm{P}}, C_{\mathrm{A}}$, and $C_{\mathrm{L}}$ are the concentrations of analyte molecules in the polymer coating, air, and liquid, respectively. $K_{\mathrm{P}-\mathrm{A}}$ and $K_{\mathrm{L}-\mathrm{A}}$ are the partition coefficients of polymer-air and liquid-air pairs. $K_{\mathrm{P}-\mathrm{A}}$ and $K_{\mathrm{L}-\mathrm{A}}$ can be calculated using a linear solvation energy relationship (LSER), ${ }^{12,13}$ provided that the appropriate LSER parameters are available. Partition coefficients provide insight into the extent of analyte partitioning into the coating, which can be directly related to the mass loading contribution to sensor response in these systems. The polymer shear modulus, $G$, is expressed by $G=G^{\prime}+j G^{\prime}$ ', where $G$ is the shear storage modulus, representing acoustic energy storage, and $G^{\prime}$ ' is the shear loss modulus, representing acoustic energy dissipation or loss. 17 Changes in the viscoelastic properties of the chemically sensitive or waveguiding layer may also contribute to the observed frequency shift when guided SH-SAW sensors are exposed to aqueous analytes. This effect has been noted in gas-phase SAW sensor studies where the viscoelastic contribution to the observed frequency shift was defined in terms of swelling-induced modulus changes $\frac{18,19}{1}$ as,

Analytical Chemistry, Vol 77, No. 14 (2005): pg. 4595-4603. DOI. This article is (C) American Chemical Society and permission has been granted for this version to appear in e-Publications@Marquette. American Chemical Society does not grant permission for this article to be further copied/distributed or hosted elsewhere without the express permission from American Chemical Society. 
NOT THE PUBLISHED VERSION; this is the author's final, peer-reviewed manuscript. The published version may be accessed by following the link in the citation at the bottom of the page.

$$
\Delta \mathrm{f}_{\mathrm{v}}=\left(\frac{\Delta f_{\mathrm{g}} C_{\mathrm{A}} K}{\rho_{\mathrm{s}}}\right)+f_{\mathrm{A}}\left(\frac{C_{\mathrm{A}} K}{\rho_{\mathrm{A}}}\right)\left(\frac{\Delta f_{\mathrm{s}} A_{\mathrm{SAW}}}{\alpha}\right)
$$

The first term represents the effect of mass loading and the second term represents the swelling-induced modulus change, which is modeled in terms of free volume changes due to thermal expansion. ${ }^{18,19} \Delta f_{\mathrm{s}}$ represents the frequency shift due to the amount of sorbent phase; $K$ is the partition coefficient, the ratio of the concentration of analyte in the sorbent phase to the concentration of the analyte in the vapor phase, $C_{A} ; \rho_{S}$ is the density of the sorbent phase; $\rho_{A}$ is the density of the vapor as a liquid; $A_{\text {Saw }}$ represents the kilohertz change in frequency due to a $1{ }^{\circ} \mathrm{C}$ change in temperature per kilohertz of coating on the device surface; $a$ is the coefficient of thermal expansion of the polymer, i.e., the fractional volume increase per degree; and $f_{\mathrm{A}}$ is the fractional free volume of the diluent (vapor) as a liquid. The parameters in eq 2 consist of those that are vapordependent, $f_{\mathrm{A}}, C_{\mathrm{A}}$, and $\rho_{\mathrm{A}}$, and those that are strictly polymerdependent, $\rho_{\mathrm{s}}, A_{\mathrm{SAW}}$, and a. However, in aqueous environments, the parameters $K, f_{\mathrm{A}}, A_{\mathrm{SAW}}$, and a have to account for effects due to both the analyte and water molecules. Therefore, it is difficult to use this equation in aqueous detection.

In this work, a comprehensive approach to investigate and determine design considerations for implementing high-sensitivity guided SH-SAW chemical liquid phase sensors is presented, combining experiments with theoretical modeling when appropriate. Experimental and theoretical analyses in the liquid phase are presented for two multilayer sensor geometries using various chemically sensitive layers, coating thickness combination, and coating curing methodologies. Coating properties are studied in order to investigate each contribution from both mass loading and polymer viscoelasticity effects. Partition coefficients for polymer-aqueous analyte pairs are used to explain the observed trend in sensitivity for the polymers (poly(methyl methacrylate) (PMMA), poly(isobutylene) (PIB), poly(epichlorohydrin) $(\mathrm{PECH})$, and poly(ethyl acrylate) (PEA)) used in this work.

Analytical Chemistry, Vol 77, No. 14 (2005): pg. 4595-4603. DOI. This article is (C) American Chemical Society and permission has been granted for this version to appear in e-Publications@Marquette. American Chemical Society does not grant permission for this article to be further copied/distributed or hosted elsewhere without the express permission from American Chemical Society. 
NOT THE PUBLISHED VERSION; this is the author's final, peer-reviewed manuscript. The published version may be accessed by following the link in the citation at the bottom of the page.

\section{Theoretical Analysis}

Theoretical analysis is performed for two sensor geometries, which describe the device in contact with the polymer overlayers and the liquid load. The geometries for the three-layer (substrate-polymer coating layer-liquid layer) and four-layer (substrate-polymer coating layer 1 -polymer coating layer 2-liquid layer), representing the sensing system, are shown in Figure 1. In the three-layer geometry, the viscoelastic layer serves as both a waveguiding layer and a chemically sensitive layer while in the four-layer geometry, polymer 1 functions as a waveguiding layer and polymer 2 acts as the chemically sensitive layer. In each case, polymers are viscoelastic and the liquid layer is assumed to be a Newtonian fluid, since the solutions of interest are very dilute aqueous solutions. The liquid layer and substrate are considered as semi-infinite layers while the polymer coating is considered as a finite layer. The metallized surface of the guided-SH-SAW devices is perturbed by the mechanical properties of the adjacent layer.
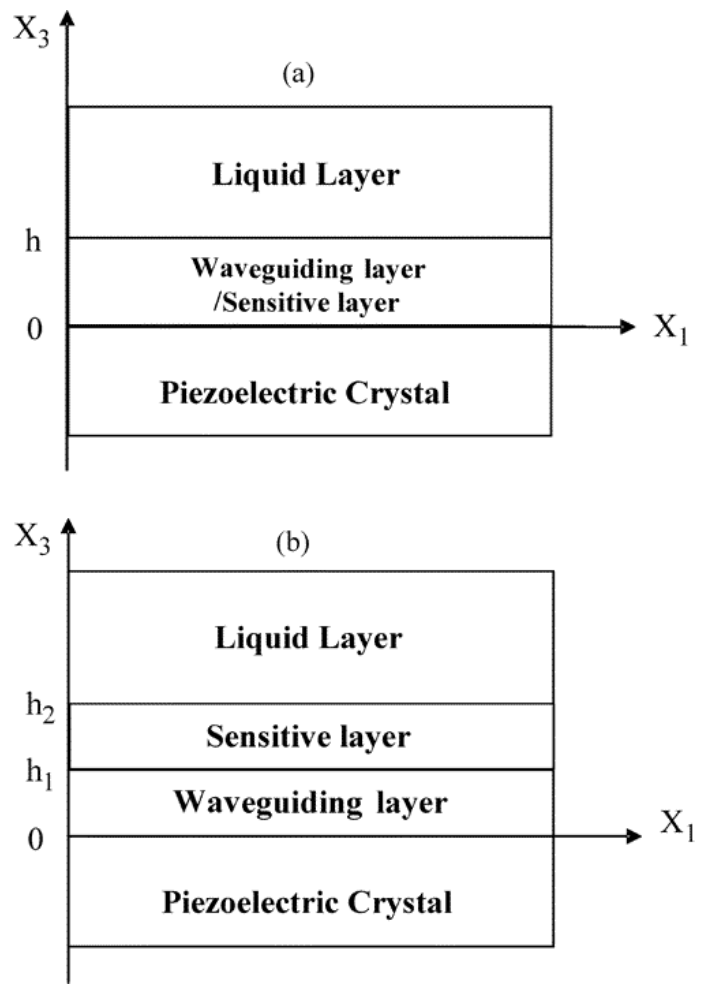

Figure 1 Geometries representing the chemical sensor configurations. Also shown is the coordinate system used in the modeling. Only mechanical perturbation is assumed. (a) Three-layer; (b) four-layer.

Analytical Chemistry, Vol 77, No. 14 (2005): pg. 4595-4603. DOI. This article is (C) American Chemical Society and permission has been granted for this version to appear in e-Publications@Marquette. American Chemical Society does not grant permission for this article to be further copied/distributed or hosted elsewhere without the express permission from American Chemical Society. 
An approximate solution for the sensor response using Auld's perturbation theory 20 is derived (Supporting Information). This method is only valid in the case where the acoustic fields before and after perturbation are not very different and the power flow integration can be executed. The aim of the theoretical analysis presented here is to provide a basis for evaluating the various contributions to the sensor response. These contributions include mass loading and viscoelastic loading. The theoretical analysis also provides the foundation for ultimately optimizing the sensor design characteristics.

\section{Experimental Section}

Devices. The guided SH-SAW device used in this work is designed and fabricated on $36^{\circ} \mathrm{YX}-\mathrm{LiTaO}_{3}$ piezoelectric substrate. Polymer coatings are used as the waveguiding layer or partially selective chemically sensitive layer. The device is fabricated with 10/90-nm-thick $\mathrm{Cr} / \mathrm{Au}$ split finger IDTs having a periodicity of $40 \mu \mathrm{m}$. This corresponds to an operating frequency of $\sim 103 \mathrm{MHz}$ for the uncoated devices. A dual delay line configuration is used that consists of a reference line and a sensing line. This configuration is used to make all the secondary interaction controls unnecessary. A metallized delay path was used between the input and output IDTs in order to eliminate the acoustoelectric interaction with any perturbation on the surface. The selected coating, a dielectric material, also helps to reduce acoustoelectric interactions and provides sufficient electrical passivation of the IDTs, due to the relatively larger dielectric constant of the piezoelectric substrate.

Coating and Solution Preparation. Both three-layer and fourlayer sensor geometries were investigated experimentally. For each configuration, a PMMA waveguiding layer was coated onto the reference line. For the four-layer geometry, PMMA was also first coated onto the sensing line, after which the chemically sensitive polymer was deposited. PMMA was deposited onto the device surface (over the IDTs and the delay path) by spin-coating solutions of 15 or $20 \% \mathrm{w} / \mathrm{v}$ PMMA in 2-ethoxyethyl acetate and then cured at $180^{\circ} \mathrm{C}$ for $2 \mathrm{~h}$. The chemically sensitive polymers used were PIB, PECH, and PEA. The PIB layer was deposited onto the sensing line using $2.25-2.90 \% \mathrm{w} / \mathrm{v}$ in chloroform, $\mathrm{PECH}$ using $3-4 \% \mathrm{w} / \mathrm{v}$ in chloroform, and PEA using 
$50-67 \%$ of PEA solution in toluene. The adhesion and stability of these sensor coatings are improved by first cleaning the device surface, then by exposing the device to ambient air, or by heating the coated devices for $15 \mathrm{~min}$ at 40 or $60^{\circ} \mathrm{C}$. Film thicknesses of $0.2-1.0 \mu \mathrm{m}$ were obtained by using different solution concentrations or spin coating speeds. The thickness of PMMA films was determined using profilometry. For other polymer materials that were too soft for accurate characterization via profilometry, thickness calibration was achieved by using an identical coating methodology on a TSM resonator. For the rubbery polymers such as PIB, PECH, and PEA, an error of $\sim 10 \%$ on the coating thickness is estimated for thin films. Sauerbrey equation was also used to determine film thicknesses from the TSM response. Care was taken to keep the thicknesses in the range $(\leq 1 \mu \mathrm{m})$ where the Sauerbrey equation approximation is still valid.

Aqueous analyte solutions (1-60 ppm) of ethylbenzene, xylenes, and toluene were prepared by dispensing the appropriate amount of the analyte into a large volumetric flask, which had been previously filled to capacity with a premeasured volume of Milli-Q deionized water. This ensured minimization of headspace in the flask. The flasks were immediately capped and sealed with Teflon tape. The resulting solutions were then vigorously shaken periodically over a period of at least $5 \mathrm{~h}$ and transferred to Teflon lined vials. Extreme care was taken to minimize volatilization of the analytes from solution.

Reagents. All polymers and solvents were used as supplied by Aldrich (Milwaukee, WI) without any further purification unless otherwise specified: chloroform (99.8\%), 2-ethoxyethyl acetate, PMMA, PIB, PECH, and PEA. All analyte samples were prepared from analytical-grade reagents, purchased from Aldrich and used as received: toluene $(99.5 \%)$, ethylbenzene $(99 \%)$, xylenes (mixed isomers, $98.5 \%)$, and nitrobenzene (99\%). For all testing, deionized (DI) water was used.

Procedures. The experimental system consists of the measurement system, the sensing system, and the liquid sample delivery system. The measurement system is composed of a network analyzer (Agilent 8753ES), switch/control unit (Agilent 3499A), and

Analytical Chemistry, Vol 77, No. 14 (2005): pg. 4595-4603. DOI. This article is @ American Chemical Society and permission has been granted for this version to appear in e-Publications@Marquette. American Chemical Society does not grant permission for this article to be further copied/distributed or hosted elsewhere without the express permission from American Chemical Society. 
PC-based HP VEE software for automatically collecting data (loss, phase, frequency). The network analyzer is used for the initial device characterization and for the sensing experiment with a switch/control unit to switch from the reference line to the sensing line and from one channel to another. The sensing system consists of the guided $\mathrm{SH}$ SAW devices, the mounting elements, and a cell made from brass and Lexan. A specially designed flow-through cell is used to expose each guided SH-SAW dual delay line to the chemical liquid-phase environment.

The liquid sample delivery system consists of a pump, working solution vials, a waste tank, and the connecting tubes.

The liquid sample delivery system is activated after the device is stabilized in DI water. The selected low flow rate $(0.2 \mathrm{~mL} / \mathrm{min})$ is used to minimize the hydrodynamic coupling between flowing liquid and the crystal surface, as the pressure and pulsating flow effects on the sensor surface may add to the sensor noise. Care is taken to avoid the existence of air pockets in the cell, which may cause change in the boundary condition at the device surface. After stabilizing the device in DI water, a PC-based HP-VEE control program is activated to collect the data (insertion loss, frequency, phase) from both channels by controlling the switch unit.

A typical run is started by pumping DI water through the cell at a selected rate and then exposing the device to the analyte solutions. Extreme care was taken to minimize volatilization of the analytes from solution. Between exposures to different sample solutions, the devices were flushed with DI water to remove the analyte and make the response return to the baseline. Prior to making measurements for a given analyte, the device coatings are conditioned by exposure to 50 ppm aqueous solutions of the analyte for $10 \mathrm{~min}$ in order to improve the stability of the device response as well as the reproducibility of initial measurements. After conditioning, the device is alternately exposed to the DI water and the analyte solution. The optimal design of the guided SH-SAW sensors for liquid-phase detection is studied by appropriate selection of the chemical sensitive polymer, and by varying the polymer curing conditions and the thickness combinations.

Analytical Chemistry, Vol 77, No. 14 (2005): pg. 4595-4603. DOI. This article is (C) American Chemical Society and permission has been granted for this version to appear in e-Publications@Marquette. American Chemical Society does not grant permission for this article to be further copied/distributed or hosted elsewhere without the express permission from American Chemical Society. 
NOT THE PUBLISHED VERSION; this is the author's final, peer-reviewed manuscript. The published version may be accessed by following the link in the citation at the bottom of the page.

\section{Results and Discussion}

The objective of this paper is to investigate and determine the parameters that influence the implementation of high-sensitivity polymer guided SH-SAW chemical sensors for the direct, rapid, and reproducible detection of (bio)chemical contaminants in liquids. All figures show the frequency shifts and loss changes relative to pure water and the reference line. Figure 2a shows a typical measured frequency shift response of a guided SH-SAW sensor device to varying concentrations of xylenes (10-60 ppm) in DI water. The sensing line of the device is coated with $0.8-\mu \mathrm{m}$-thick PIB, and the reference line is coated with 0.8- $\mu \mathrm{m}$-thick PMMA. In this case, the PIB layer was not cured while the PMMA coating was cured at $180^{\circ} \mathrm{C}$. For direct detection of 10-60 ppm xylenes in water, the sensor exhibits excellent reversibility when the analyte is removed by subjecting the device to DI water. As shown in Figure 2a, an apparent response time of 10 min is observed. This does not represent the actual sensor response time, however. Due to the low flow rate of the aqueous analyte sample into the sample cell and the finite size of the cell, it takes a relatively long time for the analyte solution to replace the DI water in the sample cell and accurately represent the concentration of the analyte in the sample vials. The same is true when the sensor is subjected to DI water to remove the analyte gradually and return the sensor response to the baseline. It is noted that when the sensor is directly exposed to the aqueous analyte, almost instantaneous response is observed. A pulse effect is observed each time the pump is switched on or off to change aqueous samples, as shown at the "analyte in/out" positions in Figure $2 \mathrm{a}$. The observed frequency shift is reversible and linear with the analyte concentration. The observed slight deviation from linearity can be explained by fluctuations in the solution concentration due to the volatile nature of the analytes. To further minimize these fluctuations, a sealed pressurized sample preparation and delivery apparatus should be designed. 

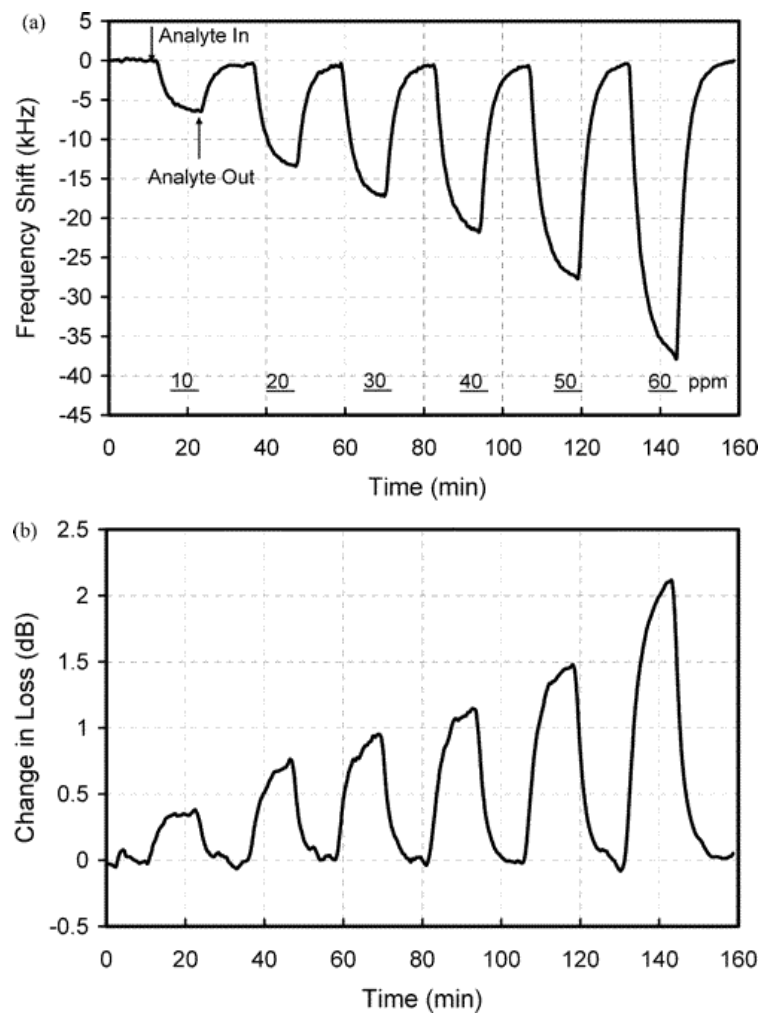

Figure 2 Detection of $10-60$ ppm xylenes using a guided SH-SAW device with 0.8 $\mu \mathrm{m}$-thick PIB on the sensing line and $0.8-\mu \mathrm{m}$-thick PMMA on the reference line. The PIB layer is uncured. (a) Change in frequency; (b) change in loss.

The measured frequency shift response in Figure 2a represents both mass loading and polymer viscoelasticity contribution as indicated by eq SI-5, shown in Supporting Information. However, this figure itself does not sufficiently provide enough insight into the role of each contribution to the sensor response. By simultaneously measuring the device loss as a function of analyte concentration in Figure $2 b$, additional information on viscoelastic contribution to the sensor response is provided. Clearly, the observed loss differences can be explained by changes in the viscoelastic properties of the load, i.e., chemically sensitive layer upon analyte sorption. As a result, both frequency response and insertion loss response indicate that the two major contributions to the sensor response are from the added analyte mass and subsequent changes in viscoelastic properties. Further analysis comparing theory and experiments has been performed and will be shown later in order to distinguish the contributions from both effects. Also, the observed (nonlinear) change in loss, especially at higher concentrations, provides a second parameter for signal processing and pattern recognition in the design of sensor arrays.

Analytical Chemistry, Vol 77, No. 14 (2005): pg. 4595-4603. DOI. This article is @ American Chemical Society and permission has been granted for this version to appear in e-Publications@Marquette. American Chemical Society does not grant permission for this article to be further copied/distributed or hosted elsewhere without the express permission from American Chemical Society. 
To achieve the objective outlined in the introduction, two different sensor geometries are analyzed theoretically and experimentally. The waveguide layer thickness effect, the chemically sensitive layer thickness effect, and the coating curing condition effect in terms of sensitivity and stability are studied in order to optimize the sensor design. Coating properties are explored in order to identify contributions from both mass loading and polymer viscoelasticity effects. Appropriate screening for chemically sensitive coating for liquid-phase detection is also needed for the polymer selection. Benzene is replaced with nitrobenzene for safety reasons.

Effects of Coating Thickness. A series of experiments that systematically varied waveguide/sensitive layer thickness combinations have been performed to determine the optimal sensor geometry and thickness combination effect. This was achieved by using different thicknesses of PIB in the three-layer geometry and different thickness combinations of PIB and PMMA in the four-layer geometry. Figure 3 shows the response for sensors (reference line cured at $180^{\circ} \mathrm{C}$ and sensing line cured at $40^{\circ} \mathrm{C}$ ) exposed to $10-60$ ppm ethylbenzene. In Figure 3a, the thickness of the waveguiding layer on the sensing line of the sensor is $0.0,0.2$, and $0.5 \mu \mathrm{m}$, while the thickness of the chemically sensitive layer on the sensing line was fixed at $0.8 \mu \mathrm{m}$. A decrease in sensitivity is observed, caused by the added PMMA, a glassy polymer. The theoretical calculations, using eq SI-5 and assuming no change in the viscoelasticity of the layer for a 0.2 - or $0.5-\mu \mathrm{m}$ PMMA waveguiding layer, show a drop in sensitivity by 15 and $36 \%$. This is consistent with observed experimental results that the three-layer geometry is more sensitive than the four-layer geometry. A second set of experiments was performed using both the three-layer geometry and the four-layer geometry. Figure $3 \mathrm{~b}$ shows results with the total thickness of PMMA and PIB coatings on the sensing line at $0.8 \mu \mathrm{m}$. The thickness of the PMMA coating varies from $0.0,0.3,0.4$, to $0.5 \mu \mathrm{m}$ while the thickness of the PIB coating changes from $0.8,0.5,0.4$, to $0.3 \mu \mathrm{m}$, respectively. It is clear from the results that the sensor with no PMMA waveguide coating (three-layer geometry) shows the greatest sensitivity. The PMMA layer, a glassy polymer, provides less capability of sorption than PIB. Therefore, fewer analyte molecules can be partitioned into the coating, causing lower 
sensitivity. The magnitude of the sensitivity decreases with increasing thickness of the waveguide layer while decreasing the thickness of the sensing layer. Theoretical calculations also confirm the above results. For example, the calculated sensitivity using eq SI-5 for a device coated with $0.3-\mu \mathrm{m}$ glassy PMMA polymer and $0.5-\mu \mathrm{m}$ rubbery PIB polymer (four-layer geometry) is only $38 \%$ of that of a device with only 0.8- $\mu \mathrm{m}$ PIB rubbery polymer (three-layer geometry). The decrease in sensitivity can be attributed to the decrease in the thickness of the sensing layer; however, from Figure $3 a$, it is seen that the sensitivity decreases with increasing waveguide thickness even when the sensing layer thickness was fixed. Experiments with uncured $\left(23^{\circ} \mathrm{C}\right)$ coatings on the sensing line also show similar conclusion. Typical experimental errors are shown with error bars in Figure 3b.
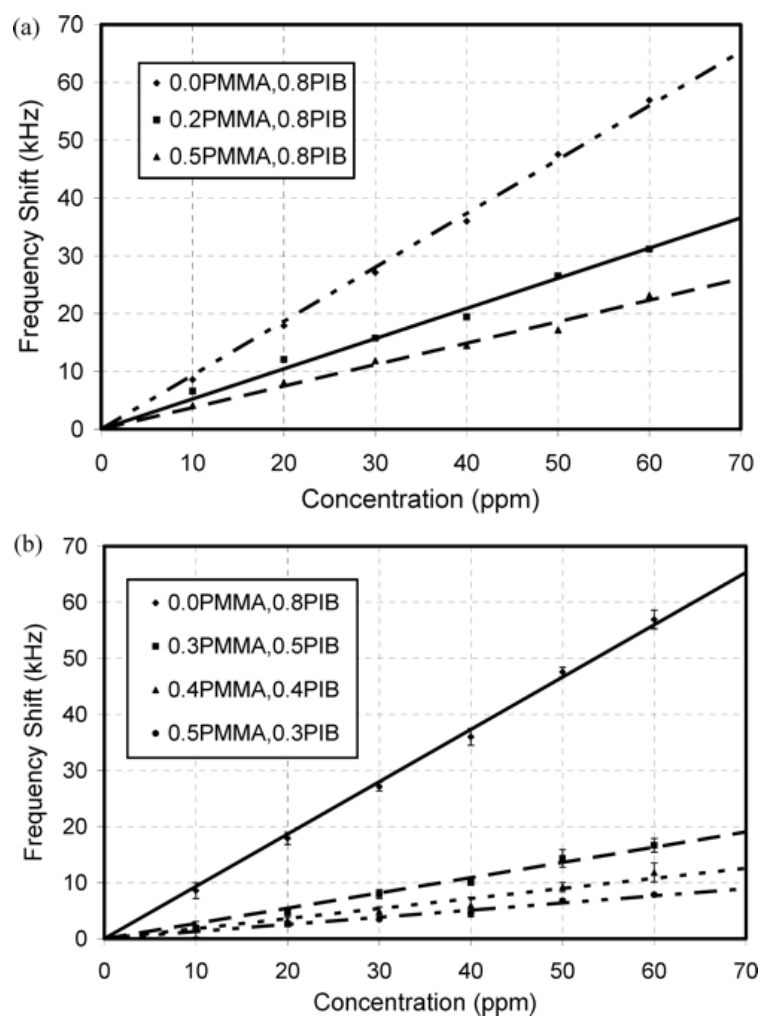

Figure 3 Sensor responses to $10-60$ ppm samples of ethylbenzene for varied thickness (unit, $\mu \mathrm{m}$ ) combinations of PMMA waveguide and PIB.

Using the three-layer geometry, other sensor parameters are studied. The measured frequency shifts of the guided SH-SAW sensor device in the detection of xylenes with different coating thicknesses in the three-layer geometry is shown in Figure SI-1 (Supporting

Analytical Chemistry, Vol 77, No. 14 (2005): pg. 4595-4603. DOI. This article is @ American Chemical Society and permission has been granted for this version to appear in e-Publications@Marquette. American Chemical Society does not grant permission for this article to be further copied/distributed or hosted elsewhere without the express permission from American Chemical Society. 
Information). The reference line of the device is coated with $0.5-, 0.8-$, or $1.0-\mu \mathrm{m}$-thick PMMA cured at $180^{\circ} \mathrm{C}$, and the sensing line is coated with the same thickness of uncured PIB. As expected, it is shown that increasing the polymer thickness increases the sensitivity. In part, this is due to increased mass loading in the thicker films caused by the increase in the polymer volume that can absorb the analyte. Moreover, the increase in analyte concentration in the coating also results in increased expansion in the polymer volume (swelling) as well as increased plasticization. It is also expected that, as the polymer film thickness increases, contributions from the change in viscoelasticity of the polymer from thin-film to bulk values will increase. The polymer becomes softer as it expands due to swelling and plasticization effects, resulting in a decrease of polymer storage modulus and an increase in the loss modulus. Moreover, it is noticed that the response time is also increased with increasing thickness of the polymer, as expected. Thus, a compromise in the selection of thickness must be made, combining a good sensitivity and fast response time for an optimum film thickness. The loss responses do not scale linearly because of the increased viscoelastic effect for thicker films. In summary, for chemical sensor applications, the three-layer system is the most sensitive geometry, with a sensor signal stability of $\sim 50 \mathrm{~Hz}$ peak-to-peak, as measured with the network analyzer for PIB and PECH-coated devices. It is noted that the sensor signal stability refers to the short-term stability of the measured sensor signal as the polymer-coated device is subjected to pure water. However, the four-layer less-sensitive system is more stable with a sensor signal noise of $\sim 30 \mathrm{~Hz}$ peak-to-peak. This is because the single layer is acting as both the guiding layer and the chemically sensitive layer. Therefore, any perturbation of that layer due to the sorption of any chemical compounds directly affects the wave guidance, dramatically affecting the sensitivity. To increase the sensitivity of the four-layer geometry, a careful selection of guiding polymer layer and chemically sensitive layer must be done, considering both mass loading effect and viscoelasticity effect.

Effect of the Coating Curing Temperature. Figure 4a shows the comparison of sensitivity of a $0.5-\mu \mathrm{m}$-thick PIB-guided SH-SAW sensor platform cured at different temperatures (uncured (23), 40, and $60^{\circ} \mathrm{C}$ ) in the detection of toluene in water. It is shown that the sensitivity decreases when the curing temperature increases. Heating 
the coatings in this temperature range will result in the removal of residual solvent. This may lead to increased intermolecular interaction between the polymer chains, effectively decreasing the free volume in the coating (i.e., lowering the ability of the analyte to penetrate the coating) and also potentially changing the shear modulus. Another way of explaining this is that, at higher curing temperature, the polymer becomes glassier, thus less prone to analyte adsorption. This can be also explained by the effect of mass loading change and polymer viscoelasticity decrease. When the polymer is cured at higher temperatures, the analyte may not produce the same degree of swelling or plasticization, resulting in the smaller decrease of the shear modulus (or smaller increase of the shear loss modulus) of the coating. This, in turn, produces smaller change in the acoustic wave velocity, hence frequency shifts of the device.
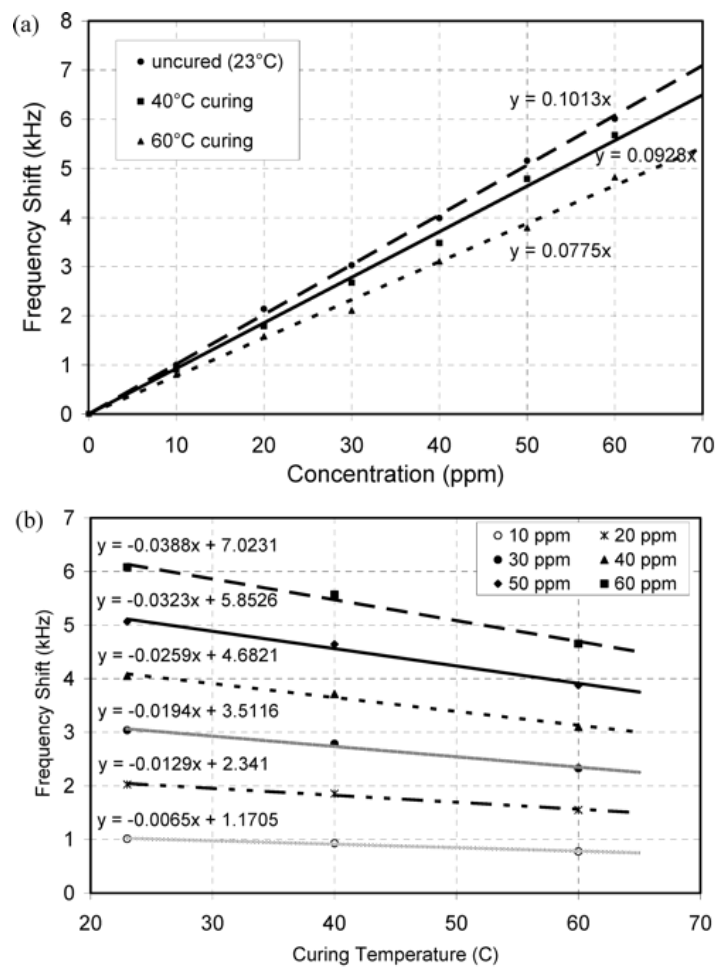

Figure 4 Effect of curing temperature. (a) Comparison of sen-sor responses of $0.5-\mu m$ PIB-coated SH-SAW device in detection of $10-60 \mathrm{ppm}$ toluene. PIB is cured at different temperatures (uncured (23), 40, and $60^{\circ} \mathrm{C}$ ). (b) Frequency shift vs curing temperature for a $0.5-\mu \mathrm{m}$ PIB-coated SH-SAW device for toluene aqueous detection at different concentrations.

Analytical Chemistry, Vol 77, No. 14 (2005): pg. 4595-4603. DOI. This article is (C) American Chemical Society and permission has been granted for this version to appear in e-Publications@Marquette. American Chemical Society does not grant permission for this article to be further copied/distributed or hosted elsewhere without the express permission from American Chemical Society. 
At higher curing temperatures, smaller device loss as a function of analyte concentration is also observed, thus confirming the above statement. Additionally, the sensor stability also increases and sensor signal noise decreases when the coatings are cured at higher temperature. For example, the noise level decreases to less than 30 $\mathrm{Hz}$ for coatings cured at $40^{\circ} \mathrm{C}$. The result is a tradeoff between high sensitivity and stability, with curing of the (rubbery) coating at $40^{\circ} \mathrm{C}$ providing a good compromise.

By replotting Figure $4 a$, the frequency shift versus coating curing temperature for a PIB-guided SH-SAW sensor in the detection of 10-60 ppm toluene can be visualized in Figure 4b. From this figure, an empirical equation can be obtained, which characterizes the response as,

$$
\Delta f_{\mathrm{PLB}}=\epsilon\left(-6.5 \times 10^{-4} T+1.18\right)
$$

where $\Delta f$ is the frequency shift (in $\mathrm{kHz}$ ), $c$ is the toluene concentration (in ppm), and $T$ is the curing temperature (in ${ }^{\circ} \mathrm{C}$ ). The usefulness of this type of equation is in the estimation of the device response in the detection of aqueous toluene in the "low" concentration range. For a complete characterization, such equations must be obtained for different coatings at thickness of interest. Low concentration is defined here as the concentration range that obeys the linear sorption isotherm. A linear sorption isotherm represents ideal solution behavior and is classified as type I sorption. ${ }^{26}$ In this type of sorption, the frequency response is linearly proportional to the concentration, as indicated by eq 3.

\section{Mass Loading and Viscoelastic Contributions to Sensor}

Responses. The contribution of mass loading to the sensor response is well accepted in this field while the contribution of the viscoelastic property of polymer coating is still under investigation, even in gasphase sensors. ${ }^{18,19,25-27}$ Unfortunately, results in gas phase cannot be totally adapted or used to explain liquid-phase responses. For example, ongoing work in liquid-phase sensing has also shown that for a rubbery polymer such as PDMS viscoelasticity changes can clearly dominate sensor response. 11,28 Understanding the effects of polymer viscoelasticity may have greater importance for liquid-phase detection 
where the polymer may swell due to both water and analyte sorption as well as plasticize due to analyte sorption. Therefore, both swelling and plasticization will affect the sensor response. The relative contribution of each effect is next assessed both experimentally and theoretically using the three-layer sensor geometry.

The changes in film height and density upon sorption of aqueous analyte are estimated using an approach adapted from the mass loading model of gas phase. ${ }^{21}$ The equations in the gas phase are extended to account for water partitions in the polymer. The effects of water and analyte are assumed to be additive. After exposure to aqueous analyte solution, the film height, $h(c)$, and density $\rho(c)$, can then be defined, respectively, as

$$
\begin{array}{r}
h(c)=h_{0}\left(1+C_{\mathrm{a}} V_{\mathrm{a}}+C_{\mathrm{w}} V_{\mathrm{w}}\right) \\
\rho(c)=\frac{\rho_{0}+C_{\mathrm{a}} M_{\mathrm{a}}+C_{\mathrm{w}} M_{\mathrm{w}}}{\left(1+C_{\mathrm{a}} V_{\mathrm{a}}+C_{\mathrm{w}} V_{\mathrm{w}}\right)}
\end{array}
$$

where

$$
C_{\mathrm{a}}=K_{\mathrm{P}-\mathrm{L}^{L}} C / M_{\mathrm{a}}
$$

and $\rho_{0}$ and $h_{0}$ are the initial unperturbed film density and thickness; $K_{\mathrm{P}-\mathrm{L}}$ is the polymer/liquid partition coefficient; $c$ is the concentration of aqueous solution; $C_{a}$ is the concentration of analyte in the polymer film; $C_{\mathrm{w}}$ is the concentration of water in the polymer $(\mathrm{mol} / \mathrm{mL})$ and is calculated based on the reported uptake of less than $0.02 \%$ water by mass when PIB is subjected to continuous immersion. ${ }^{17} V_{\mathrm{a}}$ and $V_{\mathrm{w}}$ are the molar volumes $(\mathrm{mL} / \mathrm{mol})$ of the aqueous analyte and water, respectively; $M_{\mathrm{a}}$ and $M_{\mathrm{w}}$ are the molar mass $(\mathrm{g} / \mathrm{mol})$ of the analyte and water, respectively.

The new thickness and density of the 0.64- $\mu m$-thick PIB polymer coating immersed in 10-60 ppm aqueous ethylbenzene, xylenes, and toluene are calculated (Supporting Information, Table SI1). Using these new values of polymer density and height, and keeping viscoelasticity constant, a calculated sensor response due to mass loading effect alone is shown in Figure 5a. A water uptake of 200 
$\mathrm{ppm}^{29}$ is incorporated into the mass loading calculation in each case when PIB is immersed into the aqueous solution. As shown in Figure $5 \mathrm{~b}$, experimental results for the 0.64- $\mu \mathrm{m}$ PIB-guided SH-SAW sensor platform in the detection of toluene, xylenes, and ethylbenzene in DI water indicate a clear discrepancy with calculations assuming mass loading alone. This suggests that the viscoelastic contribution to sensor response plays an important role in the chemical liquid sensing response.
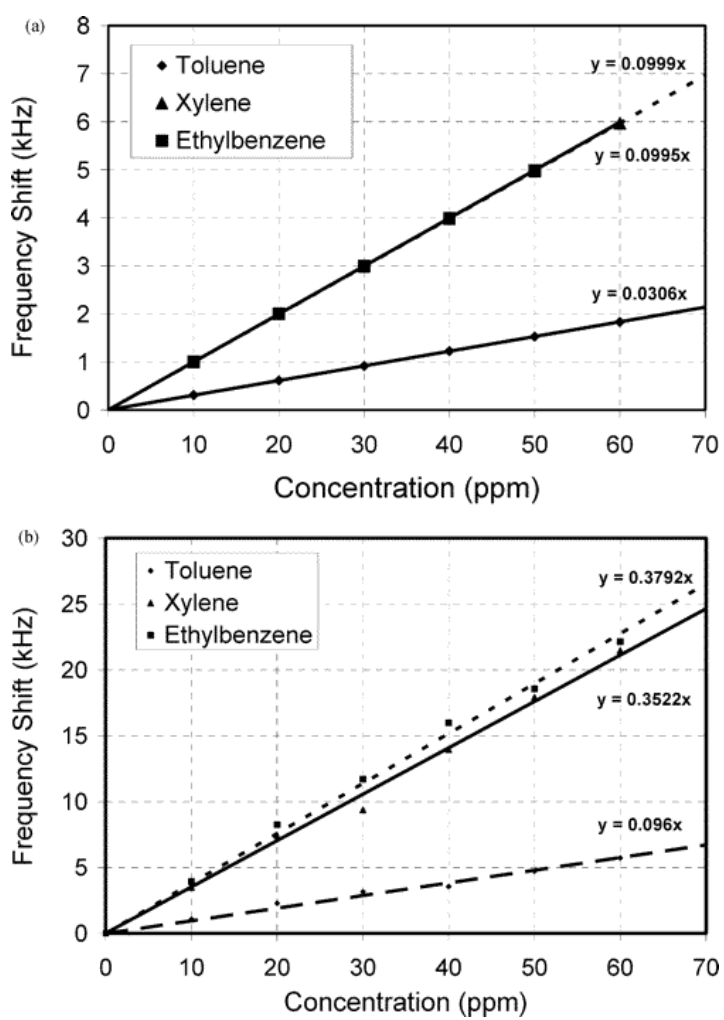

Figure 5 Sensitivity comparison of $0.64-\mu \mathrm{m}$ PIB-coated guided SH-SAW sensor platform in the detection of toluene, xylenes, and ethylbenzene in DI water. (a) Calculated responses based on the predicted added mass load derived from water-polymer partition coefficients. (b) Experimental results.

The viscoelastic property of the polymer changes upon exposure to the analyte solution. Sorption of analyte into the polymer matrix and the interaction of the analyte with the polymer cause perturbation to the polymer matrix. Upon analyte partitioning into a rubbery polymer matrix, the polymer matrix attempts to relieve the effects of analyte stressors by undertaking various conformational arrangements until a thermodynamically stable condition exists whereby the polymer exhibits equilibrium conditions. The presence of small analyte

Analytical Chemistry, Vol 77, No. 14 (2005): pg. 4595-4603. DOI. This article is @ American Chemical Society and permission has been granted for this version to appear in e-Publications@Marquette. American Chemical Society does not grant permission for this article to be further copied/distributed or hosted elsewhere without the express permission from American Chemical Society. 
molecules causes molecular chain segments to become more flexible, effectively reducing the modulus. This process is referred to as dilution, softening, or plasticization. ${ }^{21}$ The segmental mobility of the macromolecular chain determines the degree to which the polymer is plasticized. Conformational rearrangement of the polymer chains may significantly affect relaxation time of the material - the time for a material to recover to equilibrium after it is disturbed. ${ }^{21}$ As a result, these changes lead to attenuation in the acoustic wave and change in the velocity of wave propagation and hence the frequency response.

Because it is difficult to know the exact moduli value of polymer materials upon exposure to different analytes and different concentrations without separate characterization, $G$ ' and $G$ ' ' for PIB are estimated from the literature value, ${ }^{21}$ with both equal to $0.8 \times 10^{9}$ Pa for an operating frequency of $100 \mathrm{MHz}$. As a result, the propagating wave senses the film as a stiff glassy material rather than as a soft rubbery material. ${ }^{19}$ However, upon absorption of water or analytes into the polymer matrix, $G$ ' is expected to decrease, while $G$ ' ' should increase as the polymer becomes lossier. Also different analytes result in different changes in the polymer viscoelasticity, due in part to differences in their partition coefficients.

In what follows, an empirical approach employing existing data is used to extract relative changes in the shear modulus value upon analyte sorption. By measuring the acoustic loss as a function of absorbed analyte, the relative change in the shear modulus can be estimated using the relative loss change within the measured range of concentration. For example, from Figure $2 b$ showing the measured loss change versus analyte concentration, it can be seen that the polymer becomes more rubbery with increasing analyte concentration for xylenes. Similar results were obtained for other analytes, with ethylbenzene showing the highest loss at $60 \mathrm{ppm}$. Thus, for this extraction, the measured loss, $L_{a, c}$, due to $60 \mathrm{ppm}$ ethylbenzene sorption is used as the reference. The ratio of the measured loss of the 0.64- $\mu \mathrm{m}$ PIB-coated sensor to 60 ppm ethylbenzene, xylenes, and toluene is 1 to 0.83 to 0.14 . It is noted that the measured acoustic loss follows a similar trend as the partition coefficients of the analyte-polymer pairs. Thus, ethylbenzene has the largest viscoelastic 
effect on the properties of the PIB-coated device, followed closely by xylenes, with toluene having a much smaller effect.

To extract the viscoelastic values, an estimated maximum change, $\left|G_{a, c}-G_{0}\right|$, of 1 order of magnitude is assumed for the shear modulus upon exposure to $60 \mathrm{ppm}$ aqueous ethylbenzene with $G_{0}$ the initial shear modulus of the polymer before analyte sorption and $G_{a, c}$ the shear modulus of the same polymer upon exposure to one of the analytes (in the present case, ethylbenzene) under test at a concentration of $60 \mathrm{ppm}$. By calculating the ratio of the measured acoustic losses due to analyte $i$ at concentration $j$ and the reference, $L_{a i, c j} / L_{a, c}$, the change in the shear modulus as a function of analyte and concentration can be estimated, as

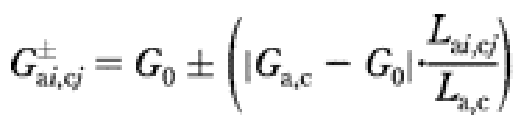

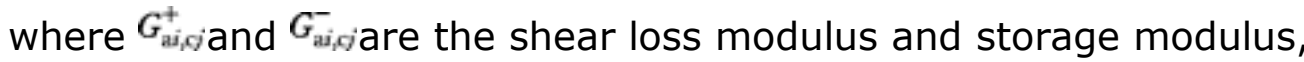
respectively, upon exposure to analyte $i$ at concentration $j$. Therefore, to use eq $6, G_{0}$ and $G_{a, c}$ have to be known and the acoustic loss responses of the polymer coated devices exposed to analytes have to be measured.

These new values of the shear modulus for 10-60 ppm of the anaytes were used in the simulation in addition to the calculated added mass to account for both mass loading and viscoelastic loading contributions. Figure 6 shows the experimental results and the predicted sensor response using eq SI-5. Upon incorporating the viscoelastic effects into the sensor response, the results show a much better prediction of the measurements, a 4-fold enhancement comparing with considering mass loading alone. This is consistent with reported amplification factors due to viscoelastic effects that are reported in the literature for gas-phase sensing, which are in the range of $2-4.18,19,25-27$

Analytical Chemistry, Vol 77, No. 14 (2005): pg. 4595-4603. DOI. This article is @ American Chemical Society and permission has been granted for this version to appear in e-Publications@Marquette. American Chemical Society does not grant permission for this article to be further copied/distributed or hosted elsewhere without the express permission from American Chemical Society. 
NOT THE PUBLISHED VERSION; this is the author's final, peer-reviewed manuscript. The published version may be accessed by following the link in the citation at the bottom of the page.

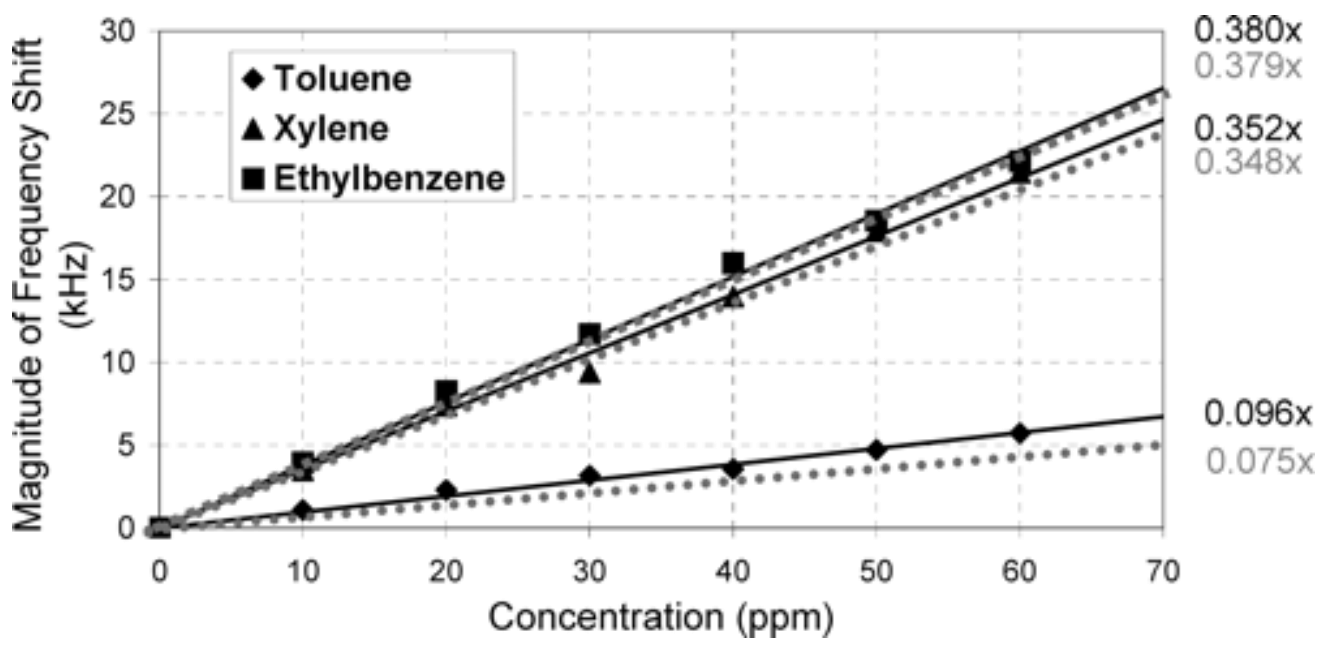

Figure 6 Selectivity comparison of $0.64-\mu \mathrm{m}$ PIB-coated guided SH-SAW sensor platform in the detection of toluene, xylenes, and ethylbenzene in DI water. - is the simulation result using predicted added mass loading and incremental viscoelastic changes based on experimental loss data. - - - is the experimental result.

\section{Coating Selection, Sensor Sensitivity, and Limit of} Detection (LOD). Appropriate selection of the chemically sensitive layer is also a critical design factor in optimizing the sensitivity of the guided SH-SAW sensor for aqueous sensing applications. Partition coefficients for the nonpolar analytes (toluene, xylenes, ethylbenzene) calculated using literature data ${ }^{13,16}$ are normalized with respect to the toluene data as 1 to 3.28 to 3.31 and compared with the normalized magnitude of the observed frequency shifts as 1 to 3.70 to 4.00 , respectively, providing a means for guiding selection of the coatings where liquid-phase partition coefficient data are available. The observed frequency shifts are in agreement with the predicted trend from the partition coefficients. Therefore, partition coefficient data is one of the effective methods for polymer-coating selection and classification as in the gas phase. Attenuated total reflectance Fourier transform infrared spectroscopy methodology for screening potentially effective coatings for SH-SAW sensors has been investigated in our previous work to predict the sorption of analytes from liquid phase into the coating materials, ${ }^{28}$ providing a new method for guiding coating selection in cases where partition coefficients are not available.

Three different polymer coatings, PIB, PECH, and PEA, are investigated as chemically sensitive layers on the guided SH-SAW device to study partial selectivity in aqueous environments. Devices coated with $0.8-\mu \mathrm{m}$ thicknesses of each layer cured at $40^{\circ} \mathrm{C}$ are 
tested in the detection of xylenes in water. Results comparing the sensitivity of these polymers to aqueous xylenes are shown in Figure SI-2 (Supporting Information), with PEA showing the highest sensitivity. Because the device response to viscoelastic effect is significant, it is not appropriate to define the sensitivity with respect to mass loading alone as is usually done with acoustic wave sensors, unless the viscoelasticity effect, also a function of absorbed analyte concentration can be defined in terms of the added mass. The device sensitivity used here is defined as frequency shift per change in solution concentration $c$ as

$$
S=\left|\frac{\Delta f}{\Delta c}\right|
$$

From Figures 3, 4, 5a, 6, 7 and 9, $S$ represents the slope of the frequency shift versus concentration curves. Using eq 7 , the LOD of a chemical sensor can then be defined as the minimum measurable concentration that corresponds to a frequency shift no smaller than three times peak-to-peak or three times the root-mean-square noise level. The LOD depends on both the sensitivity and the signal stability due to the noise ${ }^{1}$.

The contributions to device sensitivity due to mass density and coating viscoelastic property changes can be determined and the devices optimized, by investigating the thickness effect, curing condition effect, etc. Signal noise, on the other hand, depends on the device frequency of operation, coating stability in water, but also on the flow system and measurement system/circuit. Using the rootmean-square noise level, a detection limit of $25 \mathrm{ppb}$ is estimated from the present measurements for ethylbenzene, $30 \mathrm{ppb}$ for xylenes, and $75 \mathrm{ppb}$ for toluene. Figure 7 shows the measured sensor response in detection of $1 \mathrm{ppm}$ aqueous toluene, xylenes, and ethylbenzene using 0.8- $\mu \mathrm{m}$-thick uncured PECH-coated SH-SAW device. Using these results, an extrapolated limit of detection of the order of $10 \mathrm{ppb}$ or less can be achieved for toluene, ethylbenzene, and xylenes in aqueous environments using appropriately selected coatings and sensor platform configuration. 
NOT THE PUBLISHED VERSION; this is the author's final, peer-reviewed manuscript. The published version may be accessed by following the link in the citation at the bottom of the page.

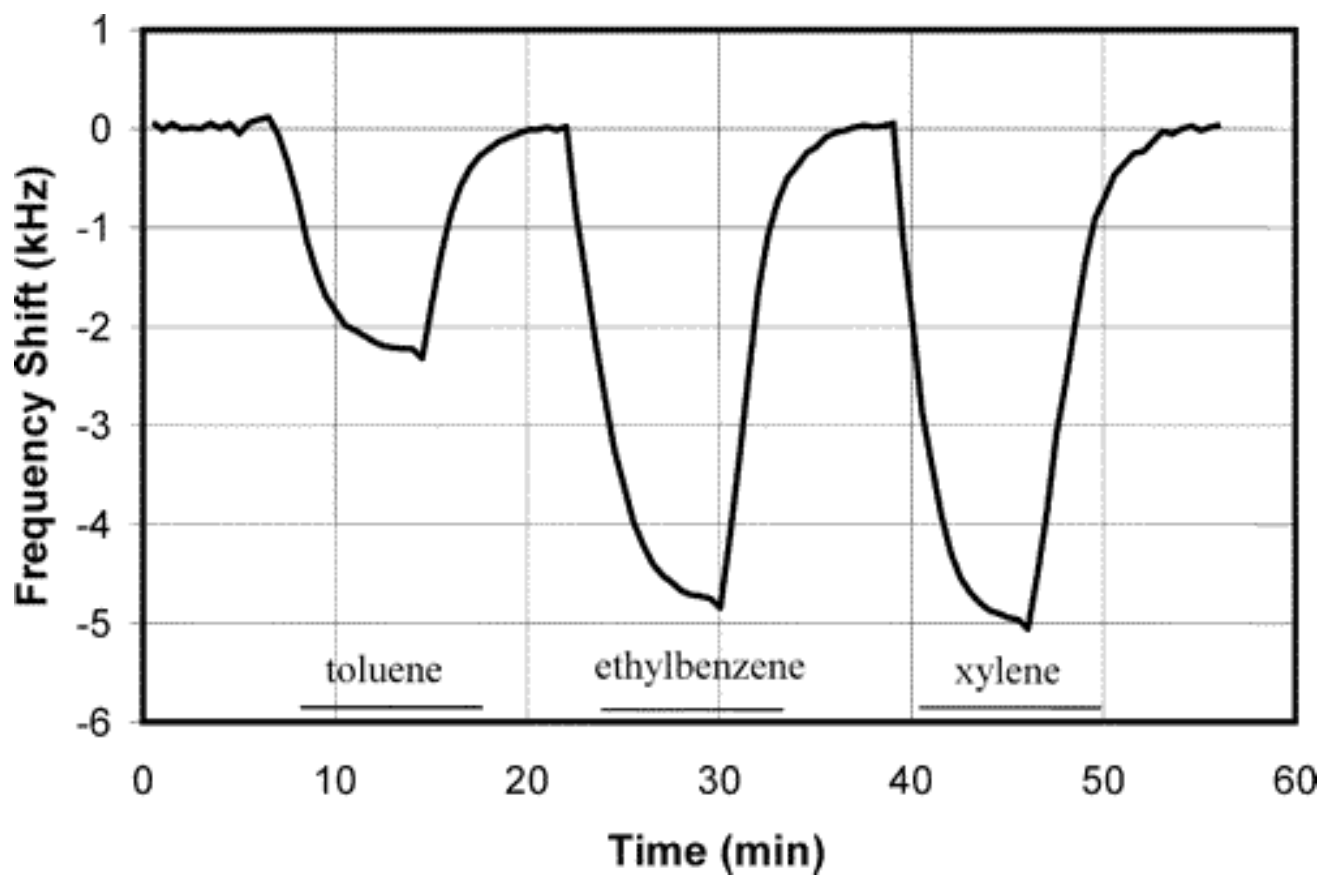

Figure 7 Comparison of sensitivity and partial selectivity of polymer PECH with $0.8-\mu \mathrm{m}$ thickness uncured device in the detection of $1 \mathrm{ppm}$ toluene, ethylbenzene, and xylenes.

\section{Conclusion}

The guided SH-SAW device on $36^{\circ} \mathrm{YX}-\mathrm{LiTaO}_{3}$ substrate has been proven to be one of the most sensitive acoustic wave liquidphase detectors. Sensor design consideration for high-sensitivity implementation requires a detailed analysis of the effects of sensor geometry as well as the properties of the chemically sensitive layer, including coating type, thickness, and changes in viscoelastic properties upon curing and aqueous analyte sorption.

Both theoretical calculation and experimental measurements show that for a given total thickness of the polymer layers on the sensing line, the three-layer model provides higher sensitivity than the four-layer model. However, the four-layer model is shown experimentally to be more stable with lower noise. This is because the single polymer layer is acting as both the guiding layer and the chemically sensitive layer. Therefore, any perturbation of that layer directly affects the wave guidance, dramatically affecting the sensitivity. Increased sensitivity when using the four-layer model can only be achieved through rigorous selection of the guiding polymer

Analytical Chemistry, Vol 77, No. 14 (2005): pg. 4595-4603. DOI. This article is (C) American Chemical Society and permission has been granted for this version to appear in e-Publications@Marquette. American Chemical Society does not grant permission for this article to be further copied/distributed or hosted elsewhere without the express permission from American Chemical Society. 
layer and chemically sensitive layer, considering both mass loading and viscoelastic effects. Viscoelastic contribution to the sensor response is significant in liquid detection. Glassy polymers show better stability while rubbery polymers show better sensitivity. Glassy polymers provide less capability for analyte sorption than rubbery polymers. This is because the polymer molecule chain matrix in glassy polymers is more densely packed and thus is less prone to analyte sorption. However, in aqueous solutions, water sorption may contribute to relaxing the polymer molecule chain matrix, thus improving the sensitivity of the glassy polymer.

As indicated by both theoretical analysis and experiments, the primary contributions to the sensor response are from the changes in mass loading and polymer viscoelasticity, both resulting from the analyte sorption in the coating. In liquid-phase detection, changes in shear moduli of the polymer can be significant. An empirical equation relating the measured changes in device loss and shear modulus of the polymer is developed to help predict and analyze the sensor response.

Furthermore, effective implementation of the sensors requires investigating various chemically sensitive layers, coating thickness, and curing methodologies for higher sensitivity and stability. Uncured chemically sensitive coatings (viscoelastic) show higher sensitivity to analyte sorption from water, but some degree of curing of the chemically sensitive layer is necessary for stability in aqueous environments. In general, a compromise has to be made to find the optimal coating thickness in terms of the sensitivity, stability, response time, and partial selectivity. The detection limits obtained from present experiments are of the order of $10 \mathrm{ppb}$ for the analytes toluene, ethylbenzene, and xylenes using an appropriately selected coating.

Good agreement is obtained between calculated partition coefficients and experiments results. As a result, despite the complex detection process (i.e., competition between water molecules and analytes) in liquid phase, partition coefficient calculations should always be the first step in the selection of the polymer coating when partition data are available, as in gas phase. 
NOT THE PUBLISHED VERSION; this is the author's final, peer-reviewed manuscript. The published version may be accessed by following the link in the citation at the bottom of the page.

\section{Acknowledgment}

This work is partially supported by NSF Grants ECS-9876366, ECS-0110381, and CHE-0074962.

\section{Supporting Information Available}

A theoretical analysis for the relative velocity and attenuation changes in terms of the polymer material and contacting liquid parameters. Additional results on the thickness effect of the polymers and their sensitivity, partial selectivity are also provided. Table SI-1 is the calculated new density and height using eqs 4 and 5 for $0.64-\mu \mathrm{m}$-thick PIB polymer coating upon exposure to aqueous analyte of toluene, ethylbenzene, and xylenes. This material is available free of charge via the Internet at http://pubs.acs.org.

\section{References}

1Ballantine, D. S.; White, R. W.; Martin, S. J.; Ricco, A. J.; Frye, G. C.; Zeller, E. T.; Wohltjen, H. Acoustic wave sensors: theory, design, and physical-chemical applications; Academic Press: New York, 1996.

²Bodenhöfer, K.; Hierlemann, A.; Noetzel, G.; Weimar, U.; Göpel, W. Anal. Chem. 1996, 68, 2210-2218.

${ }^{3}$ Grate, J. W. Chem. Rev. 2000, 100, 2627-2648.

4Grate, J. W.; Wenzel, S. W.; White, R. M. Anal. Chem. 1992, 64, 413-423.

${ }^{5}$ Bryant, A.; Poirier, M.; Riley, G.; Lee, D. L.; Vetelino, J. F. Sens. Actuators 1998, 4, 105-111.

6]osse, F.; Bender, F.; Cernosek, R. W. Anal. Chem. 2001, 73, 5937-5944.

zHarding, G. L.; Du, J.; Dencher, P. R.; Barnett, D.; Howe, E. Sens. Actuators. A 1997, 61, 279-286.

8Bender, F. R.; Cernosek, W.; Josse, F. Electron. Lett. 2000, 36 (19), 1672-1673.

9Patel, R.; Zhou, R.; Zinszer, K.; Josse, F. Anal. Chem. 2000, 72, 4888-4898.

10McMullan, C.; Mehta, H.; Gizeli, E.; Lowe, C. R. J. Phys. D: Appl. Phys. 2000, 33, 3053-3059.

11]Jones, Y. K.; Li, Z.; Josse, F.; Hossenlopp, J. M. Proc IEEE Int. Conf. Sens. 2003, 946-951.

$\underline{12}$ Grate, J. W.; Wise, B. M.; Abraham, M. H. Anal. Chem. 1999, 71, 4544-4553.

13McGill, R. A.; Abraham, M. H.; Grate, J. W. Chemtech 1994, 24 (9), 27-37.

Analytical Chemistry, Vol 77, No. 14 (2005): pg. 4595-4603. DOI. This article is (C) American Chemical Society and permission has been granted for this version to appear in e-Publications@Marquette. American Chemical Society does not grant permission for this article to be further copied/distributed or hosted elsewhere without the express permission from American Chemical Society. 
NOT THE PUBLISHED VERSION; this is the author's final, peer-reviewed manuscript. The published version may be accessed by following the link in the citation at the bottom of the page.

14Hierlemann, A.; Zellers, E. T.; Ricco, A. J. Anal. Chem. 2001, 73, 3458-3466.

15 Grate, J. W.; Abraham, M. H.; Sens. Actuators, B 1991, 3, 85-111.

16 McGill, R. A. SPE ANTEC Indianapolis Proc. 1996, 2, 2080-2084.

17Riande, E.; Diaz-Calleja, R.; Prolongo, M. G.; Masegosa, R. M.; Salom, C.: Polymer Viscoelasticity: Stress and Strain in Practice; Marcel Dekker: New York, 2000.

${ }_{18}^{18}$ rate, J. W.; Zellers, E. T. Anal. Chem. 2000, 72, 2861-2868.

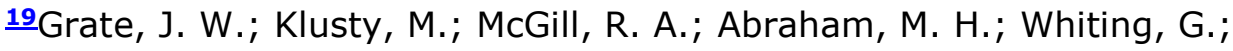
Aandonian-Haftvan, J. Anal. Chem. 1992, 64, 610-624.

20Auld, B. A. Acoustic Fields and Waves in Solid, 2nd ed.; Krieger Pub.: Malabar, 1990; Vols. I and II.

21Martin, S. J.; Frye, G. C.; Senturla, S. D. Anal. Chem. 1994, 66, 2201-2219.

22KKondoh, J.; Shiokawa, S. Electron. Commun. Jpn., Part 2 1993, 76 (2), 69-81.

$\underline{23} \mathrm{Li}$, Z.; Jones, Y.; Hossenlopp, J.; Cernosek, R. W.; Josse, F. Proc. 2003 IEEE Int. Freq. Control Symp. 2003, 918-926.

${ }^{24}$ Rogers, C. E. In Polymer Permeability; Comyn, J., Ed.; Elsevier Appl. Sci. Publ., London, 1985; Chapter 2, pp 29-34.

$\underline{25}$ Liron, Z.; Kaushansky, N.; Frishman, G.; Kaplan, D.; Greenblatt, J. Anal. Chem. 1997, 69, 2848-2854.

26Grate, J. W.; Kaganove, S. N. Anal. Chem. 1998, 70, 199-203.

27Grate, J. W.; Patrash, S. J.; Abraham, M. H. Anal. Chem. 1995, 67, 2162-2169.

28 Jones, Y. K.; Li, Z.; Johnson, M.; Josse, F.; Hossenlopp, J. M. IEEE Sens. J. In press.

299Mark, J. E. Polymer Data Handbook; Oxford University Press: New York, 1999.

Analytical Chemistry, Vol 77, No. 14 (2005): pg. 4595-4603. DOI. This article is (C) American Chemical Society and permission has been granted for this version to appear in e-Publications@Marquette. American Chemical Society does not grant permission for this article to be further copied/distributed or hosted elsewhere without the express permission from American Chemical Society. 


\title{
Supporting Information For:
}

\section{Analysis of Liquid-Phase Chemical Detection using Guided SH-SAW Sensors}

\author{
Zhonghui Li, Yolanda Jones ${ }^{l}$, Jeanne Hossenlopp ${ }^{l}$, \\ Richard Cernosek ${ }^{2}$, and Fabien Josse ${ }^{*}$ \\ Microsensor Research Laboratory and Department of Electrical and Computer \\ Engineering, 'Department of Chemistry, Marquette University, P.O. Box 1881, \\ Milwaukee, WI 53201-1881, \\ ${ }^{2}$ Micro-Analytical Systems Dept., Sandia National Laboratories, P.O. Box 5800, MS \\ 0892, Albuquerque, NM 87185-0892
}

\section{Table of contents:}

S-2 A. Theoretical Analysis

S-7 Table SI-1. New density and height for $0.64 \mu \mathrm{m}$ - thick PIB polymer coating upon exposure to aqueous analyte of toluene, ethylbenzene and xylenes.

S-8 Figure SI-1. Comparison of measured frequency shift responses of various PIB coating thicknesses in the detection of 10-60 ppm xylenes (The PIB coating is uncured).

S-9 Figure SI-2. Comparison of measured sensitivity for devices coated with $0.8 \mu \mathrm{m}$ of PIB, PECH, and PEA (cured at $40^{\circ} \mathrm{C}$ ) in the detection of $10-60 \mathrm{ppm}$ xylenes in water.

'Corresponding author. Email: fabien.josse@ marquette.edu ; Tel: 414-288-6789; Fax: 414-288-5579

$$
\text { - S-1 - }
$$

Analytical Chemistry, Vol 77, No. 14 (2005): pg. 4595-4603. DOI. This article is @ American Chemical Society and permission has been granted for this version to appear in e-Publications@Marquette. American Chemical Society does not grant permission for this article to be further copied/distributed or hosted elsewhere without the express permission from American Chemical Society. 
NOT THE PUBLISHED VERSION; this is the author's final, peer-reviewed manuscript. The published version may be accessed by following the link in the citation at the bottom of the page.

\section{A. Theoretical Analysis:}

The geometries for the analysis, representing the chemical sensor configurations, are shown in Fig 1. In the analysis, the reference configuration is the bare device in contact with DI water and the configuration after the perturbation is the coated device exposed to the DI water. Because the analyte solution is a diluted solution, at ppb-ppm level, the mechanical properties of the liquid are considered unchanged before and after perturbation.

A complex propagating factor $\beta$ is assumed, and is defined by the wavenumber $k$ and attenuation $\alpha$ as

$$
\beta=k-j \alpha=\frac{\omega}{V}-j \alpha
$$

Here, $V$ is the phase velocity of the SH-SAW, and $\omega$ is the angular excitation frequency.

The variation of the complex propagation constant is derived as

$$
\frac{\Delta \beta}{k}=-\frac{\Delta V}{V}-j \frac{\Delta \alpha}{k}
$$

where $\Delta V$ and $\Delta \alpha$ are the changes in $V$ and $\alpha$, respectively. All quantities have been normalized by the wavenumber $k$. Using perturbation theory and surface acoustic impedance techniques, ${ }^{1-2}$ the variation in the complex propagation constant can be expressed $\operatorname{as}^{2-3}$

$$
\frac{\Delta \beta}{k}=-\frac{j V\left(v^{*} \cdot Z_{A}^{\prime} \cdot v+v^{\prime} \cdot Z_{A}^{*} \cdot v^{*}\right)}{4 \omega P}
$$

where $Z_{\mathrm{A}}$ and $v$ are the surface acoustic impedance and particle velocity amplitudes, respectively; * is the complex conjugate; The prime terms $\mathrm{Z}^{\prime}$ and $v^{\prime}$ represent perturbed

$$
\text { - S-2 - }
$$

Analytical Chemistry, Vol 77, No. 14 (2005): pg. 4595-4603. DOI. This article is @ American Chemical Society and permission has been granted for this version to appear in e-Publications@Marquette. American Chemical Society does not grant permission for this article to be further copied/distributed or hosted elsewhere without the express permission from American Chemical Society. 
NOT THE PUBLISHED VERSION; this is the author's final, peer-reviewed manuscript. The published version may be accessed by following the link in the citation at the bottom of the page.

terms; $P$ is the SH-SAW acoustic power density (power per unit width). In deriving equation (SI-3), only a mechanical perturbation is assumed, with the surface electrically shorted. It is also assumed that only the surface stress is perturbed, and the particle velocity amplitude does not vary. Using equations (SI-2) and (SI-3), the relative change in velocity and the normalized attenuation are expressed as

$$
\begin{aligned}
& \frac{\Delta V}{V}=\operatorname{Re}\left[\frac{j V\left(v^{*} \cdot Z_{A}^{\prime} \cdot v+v \cdot Z_{A}^{*} \cdot v^{*}\right)}{4 \omega P}\right] \\
& \frac{\Delta \alpha}{k}=\operatorname{Im}\left[\frac{j V\left(v^{*} \cdot Z_{A}^{\prime} \cdot v+v \cdot Z_{A}^{*} \cdot v^{*}\right)}{4 \omega P}\right]
\end{aligned}
$$

Here, the theoretical analysis of the 3-layer and 4-layer models will utilize the acoustic impedance at the surface before and after perturbation caused by the liquid sensing.

In the derivation below, subscript " $f$ " and " $l$ " represent the polymer film and the liquid layer, respectively. Using the boundary conditions, which are the continuity of the particle displacement and stress at various interfaces, and the perturbation theory, the variation of the propagating factor in the 3-layer geometry of SH-SAW case can be written, accounting for all three particle displacement components, as

$$
\begin{aligned}
& \frac{\Delta V}{V}=\operatorname{Re}\left(\frac{j V}{4 \omega P} \sum_{i=1}^{3}\left[\frac{\beta_{i} M_{f}^{(i)}}{\omega} F(i)+\left(-j \frac{\beta_{c} M_{i}^{(i)}}{\omega}\right)^{*}\right] \cdot v_{i}^{2}\right) \\
& \frac{\Delta \alpha}{k}=\operatorname{Im}\left(\frac{j V}{4 \omega P} \sum_{i=1}^{3}\left[\frac{\beta_{i} M_{f}^{(i)}}{\omega} F(i)+\left(-j \frac{\beta_{c} M_{i}^{(i)}}{\omega}\right)^{*}\right] \cdot v_{i}^{2}\right)
\end{aligned}
$$

where

$$
F(i)=\frac{\left[\left(j \beta_{i} M_{f}^{(i)}+\beta_{c} M_{i}^{(i)}\right) e^{j \beta, h}-\left(j \beta_{i} M_{f}^{(i)}-\beta_{c} M_{t}^{(i)}\right) e^{-j \beta, i n}\right]}{\left[\left(j \beta_{i} M_{f}^{(i)}+\beta_{c} M_{i}^{(i)}\right) e^{j \beta, i}+\left(j \beta_{i} M_{f}^{(j)}-\beta_{c} M_{t}^{(i)}\right) e^{-j \beta, i, h}\right.} \quad \quad(i=1,2,3)
$$

Analytical Chemistry, Vol 77, No. 14 (2005): pg. 4595-4603. DOI. This article is @ American Chemical Society and permission has been granted for this version to appear in e-Publications@Marquette. American Chemical Society does not grant permission for this article to be further copied/distributed or hosted elsewhere without the express permission from American Chemical Society. 
NOT THE PUBLISHED VERSION; this is the author's final, peer-reviewed manuscript. The published version may be accessed by following the link in the citation at the bottom of the page.

$$
\begin{gathered}
\beta_{i}=\omega\left(\frac{\rho_{f}-E_{f}^{(i)} V^{2}}{M_{f}^{(0)}}\right)^{1 / 2}, \quad \beta_{c}=(1+j) \sqrt{\frac{\omega \rho_{l}}{2 \eta_{f}}}, \\
E_{f}^{(1)}=\frac{4 G_{f}\left(3 K_{f}+G_{f}\right)}{3 K_{f}+4 G_{f}}, \quad E_{f}^{(2)}=G_{f}, \quad E_{f}^{(3)} \approx 0
\end{gathered}
$$

$\beta_{\mathrm{i}}$ is the complex propagation factor for the particle displacement propagating across the film; $M_{f}^{(i)}$ is the generalized modulus for the film layer, equaling $G_{f}$ for $i=1$ or 2 and $K_{f}$ for $i=3 ; E_{f}^{(i)}$ is the Young's modulus for the polymer coating layer associated with the film deformation and contributing to the $i$ th displacement component; and $\rho_{\mathrm{f}}$ is the mass density of the film, and $M_{l}^{(i)}$ is the generalized modulus for the liquid layer, equaling $G_{l}$ for $i=1$ or 2 and $K_{l}$ for $i=3 ; \eta_{l}$ is the viscosity of the liquid; $\rho_{l}$ is the mass density of the liquid; $\beta_{c}$ is the complex shear wave propagating constant across the liquid and $v_{i}$ is the particle velocity amplitude in the $x_{i}$ direction, values of which are obtained using exact numerical analysis of the wave propagation in the piezoelectric substrate, and can be found in the literature. ${ }^{4}$

From equation (SI-5), it is evident that the sensor performance is a function of polymer material parameters (mass density, viscoelasticity, film thickness) and the liquid solution parameters. $\beta_{i}$ and $M_{f}^{(i)}$ are polymer-dependent parameters, while $\beta_{c}$ and $M_{l}^{(i)}$ are liquid-dependent parameters. Obviously, one can analyze $F(i)$ to evaluate the weight of each parameter.

If the configuration before the perturbation is the bare device, and the configuration after the perturbation is the coated device in air, which makes $M_{l}^{(i)}=0$, then equation (SI-5) will be simplified as

Analytical Chemistry, Vol 77, No. 14 (2005): pg. 4595-4603. DOI. This article is @ American Chemical Society and permission has been granted for this version to appear in e-Publications@Marquette. American Chemical Society does not grant permission for this article to be further copied/distributed or hosted elsewhere without the express permission from American Chemical Society. 
NOT THE PUBLISHED VERSION; this is the author's final, peer-reviewed manuscript. The published version may be accessed by following the link in the citation at the bottom of the page.

$$
\begin{aligned}
& \frac{\Delta V}{V}=\operatorname{Re}\left[\frac{V}{4 \omega P} \cdot \frac{\beta_{2} M_{f}^{(2)}}{\omega} \cdot \tan \left(\beta_{i} h\right) \cdot v_{2}^{2}\right] \\
& \frac{\Delta \alpha}{k}=\operatorname{Im}\left[\frac{V}{4 \omega P} \cdot \frac{\beta_{2} M_{f}^{(2)}}{\omega} \cdot \tan \left(\beta_{i} h\right) \cdot v_{2}^{2}\right]
\end{aligned}
$$

The above is similar to the result obtained in reference ${ }^{3}$ where the perturbation is due to the polymer coating only.

A similar analysis is also performed for the 4-layer geometry. The results easily reduce to those of the 3-layer geometry when the thickness of one layer is reduced to zero; or when these two coating layers are of the same type with identical mechanical properties. However due to the complexity of added boundary conditions, the results of this analysis will not be presented here. It is noted that the sensitivity of the chemically sensitive layer depends on the degree of wave guidance provided by the composite layer. ${ }^{5}$ Furthermore, a complete analysis and determination of the sensitivity of this structure will require analyzing the function $F(i)$. This will result in finding a range of thicknesses for the guidance layer (layer 1), necessary to optimize the device response. The results of the theory will be utilized to analyze experimental results, and determine the various contributions to the sensor response. In order to effectively design the guided SH-SAW sensor, a detailed investigation is needed for identifying the effects of various parameters, including the mass loading (density $\times$ thickness, $\rho$ ) effect, polymer viscoelasticity (shear storage modulus and shear loss modulus) effect, and sensor geometry comparison (threelayer $v s$. four-layer). Therefore, a series of simulations can be performed to investigate the different contributions of the design parameters using equation (SI-5). However, this can be done only after relating the measured frequency shift to the calculated velocity change. In the present case, assuming negligible dispersion, due to the energy trapping by

Analytical Chemistry, Vol 77, No. 14 (2005): pg. 4595-4603. DOI. This article is @ American Chemical Society and permission has been granted for this version to appear in e-Publications@Marquette. American Chemical Society does not grant permission for this article to be further copied/distributed or hosted elsewhere without the express permission from American Chemical Society. 
NOT THE PUBLISHED VERSION; this is the author's final, peer-reviewed manuscript. The published version may be accessed by following the link in the citation at the bottom of the page.

the waveguide layer, the relationship between the measured frequency change and velocity change can be derived as

$$
\frac{\Delta f}{f}=\frac{l_{s}}{L} \frac{\Delta V}{V}
$$

where $L$ is the IDT center-to-center distance of the device and $l_{s}$ is the sensing path length. For cases where $l_{s}$ equals $L$ (the sensitive coating is on the entire device), $\Delta f / f=\Delta V / V$.

\section{References:}

(1) Martin, S. J.; Frye, G. C.; Senturla, S. D. Anal. Chem. 1994, 66, 2201-2219.

(2) Auld, B.A. Acoustic Fields and Waves in Solids, $2^{\text {nd }}$ ed.; Krieger: Malabar, FL, 1990

(3) Kondoh, J.; Saito, K.; Shiokawa, S.; Suzuki, H. Jpn. J. Appl. Phys. 1996, 35, 30933096.

(4) Jhunjhunwala, A. PhD dissertation, Spectrum of Acoustic Wave Excited in Single and Multiple Layered Crystalline Media, 1979, University of Maine at Orono

(5) Li, Z.; Jones, Y.; Hossenlopp, J.; Cernosek, R. W.; Josse, F. Proc. 2003 IEEE Int'l Freq. Control Symp., 2003, 918-926.

Analytical Chemistry, Vol 77, No. 14 (2005): pg. 4595-4603. DOI. This article is @ American Chemical Society and permission has been granted for this version to appear in e-Publications@Marquette. American Chemical Society does not grant permission for this article to be further copied/distributed or hosted elsewhere without the express permission from American Chemical Society. 
NOT THE PUBLISHED VERSION; this is the author's final, peer-reviewed manuscript. The published version may be accessed by following the link in the citation at the bottom of the page.

\begin{tabular}{|c||c|c|c|c||c|c|}
\hline \multirow{2}{*}{$\begin{array}{c}\text { Conc. } \\
(\mathrm{ppm}= \\
\mathrm{mg} / \mathrm{L})\end{array}$} & \multicolumn{2}{|c|}{ Toluene } & \multicolumn{2}{|c|}{ Ethylbenzene } & \multicolumn{2}{|c|}{ Xylenes } \\
\cline { 2 - 4 } & $\begin{array}{c}\rho \\
\mathrm{g} / \mathrm{cm}^{3}\end{array}$ & $\begin{array}{c}\mathrm{h}\left(\times 10^{-5}\right) \\
\mathrm{cm}\end{array}$ & $\begin{array}{c}\rho \\
\mathrm{g} / \mathrm{cm}^{3}\end{array}$ & $\begin{array}{c}\mathrm{h}\left(\times 10^{-5}\right) \\
\mathrm{cm}\end{array}$ & $\begin{array}{c}\rho \\
\mathrm{g} / \mathrm{cm}^{3}\end{array}$ & $\begin{array}{c}\mathrm{h}\left(\times 10^{-5}\right) \\
\mathrm{cm}\end{array}$ \\
\hline \hline 10 & 0.91994 & 6.412 & 0.91975 & 6.435 & 0.91970 & 6.435 \\
\hline \hline 20 & 0.91986 & 6.422 & 0.91949 & 6.470 & 0.91938 & 6.469 \\
\hline \hline 30 & 0.91978 & 6.432 & 0.91923 & 6.504 & 0.91907 & 6.504 \\
\hline 40 & 0.91970 & 6.442 & 0.91897 & 6.538 & 0.91876 & 6.538 \\
\hline \hline 50 & 0.91962 & 6.453 & 0.91872 & 6.572 & 0.91846 & 6.572 \\
\hline 60 & 0.91954 & 6.463 & 0.91847 & 6.606 & 0.91816 & 6.606 \\
\hline
\end{tabular}

Table SI-1. New density and height for $0.64 \mu \mathrm{m}$ - thick PIB polymer coating upon exposure to aqueous analyte of toluene, ethylbenzene and xylenes.

- S-7 -

Analytical Chemistry, Vol 77, No. 14 (2005): pg. 4595-4603. DOI. This article is @ American Chemical Society and permission has been granted for this version to appear in e-Publications@Marquette. American Chemical Society does not grant permission for this article to be further copied/distributed or hosted elsewhere without the express permission from American Chemical Society. 
NOT THE PUBLISHED VERSION; this is the author's final, peer-reviewed manuscript. The published version may be accessed by following the link in the citation at the bottom of the page.

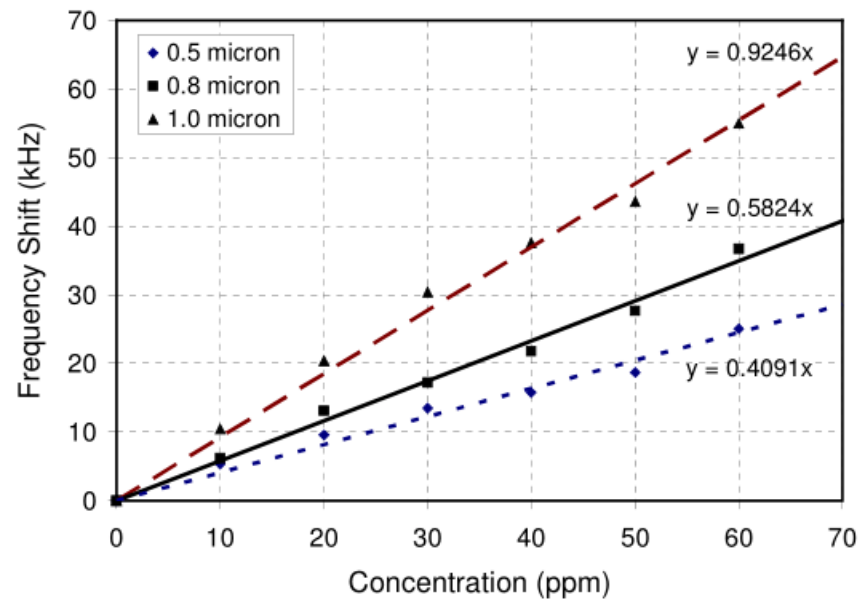

Figure SI-1. Comparison of measured frequency shift responses of various PIB coating thicknesses in the detection of 10-60 ppm xylenes (The PIB coating is uncured).

- S-8 -

Analytical Chemistry, Vol 77, No. 14 (2005): pg. 4595-4603. DOI. This article is @ American Chemical Society and permission has been granted for this version to appear in e-Publications@Marquette. American Chemical Society does not grant permission for this article to be further copied/distributed or hosted elsewhere without the express permission from American Chemical Society. 
NOT THE PUBLISHED VERSION; this is the author's final, peer-reviewed manuscript. The published version may be accessed by following the link in the citation at the bottom of the page.

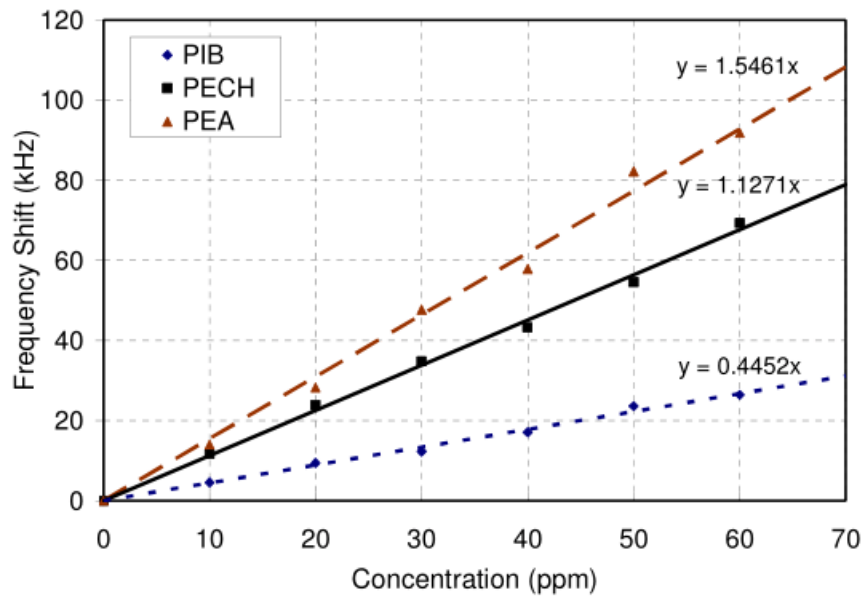

Figure SI-2. Comparison of measured sensitivity for devices coated with $0.8 \mu \mathrm{m}$ of PIB,

$\mathrm{PECH}$, and PEA (cured at $40^{\circ} \mathrm{C}$ ) in the detection of $10-60 \mathrm{ppm}$ xylenes in water.

- S-9 -

Analytical Chemistry, Vol 77, No. 14 (2005): pg. 4595-4603. DOI. This article is @ American Chemical Society and permission has been granted for this version to appear in e-Publications@Marquette. American Chemical Society does not grant permission for this article to be further copied/distributed or hosted elsewhere without the express permission from American Chemical Society. 
NOT THE PUBLISHED VERSION; this is the author's final, peer-reviewed manuscript. The published version may be accessed by following the link in the citation at the bottom of the page.

- S-10 -

Analytical Chemistry, Vol 77, No. 14 (2005): pg. 4595-4603. DOI. This article is @ American Chemical Society and permission has been granted for this version to appear in e-Publications@Marquette. American Chemical Society does not grant permission for this article to be further copied/distributed or hosted elsewhere without the express permission from American Chemical Society. 